Zaini Ibrahim

\title{
STRATEGI MENDORONG PERTUMBUHAN BANK SYARIAH DI INDONESIA
}

\begin{abstract}
Abstrak
Sebagai bagian dari dual banking system, eksistensi perbankan syariah saat ini terus menunjukkan perkembangan positif. Walaupun market share baru sebesar lima persen, namun pertumbuhan setiap tahun yang mencapai 40 persen merupakan sinyal yang membanggakan untuk tetap dipertahankan.

Identifikasi faktor pendorong kemajuan bank syariah bersumber dari internal dan eksternal. Faktor internal berupa kelangkapan regulasi. Ada dua regulasi yang signifikan mendorong akselerasi pertumbuhan perbankan syariah di tanah air, yaitu UU No. 21/2008 tentang Perbankan Syariah dan UU Pajak Pertambahan Nilai (PPN). Sedangkan faktor eksternal berupa perkembangan ekonomi global dan nasional.

Ada lima strategi yang dirumuskan oleh Bank Indonesia agar bank syraiah dapat memberi dorongan positif bagi perekonomian nasional. Pertama, mendorong pembiayaan syariah ke sektor produktif; kedua, mendorong inovasi produk agar tidak kalah dengan produk yang dipasarkan bank konvensional; ketiga, melakukan koordinasi dengan lembaga pengawas baru, yaitu Otoritas Jasa Keuangan (OJK). Strategi keempat, mendorong efisiensi bank syariah dengan cara bersinergi dengan bank induk; kelima, semakin meningkatkan sosialiasi dan edukasi agar positioning bank syariah di mata nasabah semakin kuat.
\end{abstract}

Kata Kunci: Bank syariah, OJK, strategi, pertumbuhan.

\section{Pendahuluan}

Sektor perbankan merupakan sektor yang sangat dominan dalam aktivitas perekonomian, bahkan bisa dikatakan merupakan urat nadi bagi perekonomian sebuah negara. Dikatakan demikian karena perbankan berfungsi mengalirkan investasi dari sisi surplus modal kepada defisit modal. Krisis moneter yang terjadi pada tahun 1997 disebabkan hilangnya kepercayaan masyarakat terhadap sektor perbankan.

Saat ini jumlah bank yang beroperasi di Indonesia mencapai sekitar 120 bank, dengan jumlah kantor sebanyak 16.625 unit. ${ }^{1}$ Jumlah tersebut berkurang setengah dibanding dengan sebelum terjadinya krisis yang terdapat sekitar 240 bank. Jumlah saat ini pun dinilai tidak ideal, sehingga Bank Indonesia (BI) mengeluarkan kebijakan 
kepemilikan tunggal (single presence policy/PSP). Kebijakan ini mewajibkan setiap pemegang saham hanya boleh menguasai satu bank saja. Jika memiliki saham lebih dari satu bank, maka disarankan untuk menjual sahamnya, melakukan merger, atau membentuk sebuah perusahaan induk (holding company). Diharapkan dari kebijakan PSP ini kelak jumlah bank yang beroperasi di Indonesia hanya sekitar 70 bank. Dilihat dari penguasaan aset, bank umum saat ini memiliki aset lebih dari Rp 4.262 triliun. Jumlah dana masyarakat yang terkumpul mencapai lebih dari Rp 3.542 triliun, dan rupiah yang dikucurkan untuk pinjaman kredit lebih dari Rp 4.173 triliun. $^{2}$

Dual banking system dalam sektor moneter Indonesia dimulai saat berlakunya UU No. 10 Tahun 1998 sebagai amandemen dari UU No. 7 Tahun 1992 tentang Perbankan yang memberikan landasan hukum bagi keberadaan sistem perbankan syariah. Menurut UU tersebut, selain bank konvensional diperbolehkan juga mendirikan usaha bank yang berdasarkan prinsip bagi hasil sesuai dengan syariah Islam. Eksistensi bank syariah semakin kokoh dengan diterbitkannya undang-undang tentang perbankan syariah lewat UU No. 21 tahun 2008.

Diawali dengan Bank Muamalat Indonesia, bank syariah mulai tumbuh dan berkembang di Indonesia dengan pesat. Secara perlahan dan didukung fatwa Majelis Ulama Indonesia, masyarakat mulai memanfaatkan jasa perbankan syariah. Data terakhir per Desember 2012, terdapat sebelas bank umum syariah dan 24 unit usaha syariah, serta 158 bank pembiayaan rakyat syariah (BPRS). Total terdapat 2663 kantor cabang bank maupun unit syariah di seluruh Indonesia, termasuk didalamnya BPRS. Perluasan jaringan kantor mampu meningkatkan jumlah nasabah bank syariah yang terlihat dari peningkatan jumlah total rekening. Di tahun 2011 total rekening (pembiayaan dan simpanan) mencapai 9,8 juta rekening, bertambah sebanyak 3,6 juta rekening di tahun 2012 menjadi 13,4 juta rekening. ${ }^{3}$

Berdasarkan uraian di atas, penulis tertarik untuk melakukan telaah mengenai faktor apa saja yang ikut mendorong pertumbuhan bank syariah, serta strategi yang tepat untuk meningkatkan pertumbuhan bank syariah di Indonesia.

\section{Pertumbuhan Organik Bank Syariah}

Sebelum melakukan identifikasi terhadap faktor pendorong pertumbuhan bank syariah, berikut penulis deskripsikan perkembangan organik bank syariah dengan menggunakan data terbaru per Desember 2012 yang dirilis Bank Indonesia (BI).

Pertumbuhan perbankan syariah di akhir 2012 menunjukkan kondisi yang cukup menggembirakan. Dari sisi aset, perbankan syariah mampu tumbuh sekitar 34 persen, sehingga total asetnya menjadi Rp 195 triliun. Peningkatan aset ini otomatis menambah market share bank syariah terhadap perbankan nasional menjadi sekitar 4,57 persen.

Pertumbuhan aset didukung oleh peningkatan pada penghimpunan dana pihak ketiga (DPK) yang juga mengalami pertumbuhan sebesar 27,8 persen dibanding tahun 2011 menjadi Rp 147,51 triliun. Penghimpunan DPK mayoritas didominasi oleh deposito, yaitu mencapai Rp 84,73 triliun (tumbuh 19,67 persen), tabungan $\mathrm{Rp}$ 
45 triliun (tumbuh 38,25 persen), dan giro sebesar Rp 17,71 triliun (tumbuh 47,49 persen). Dominasi deposito dalam DPK menunjukkan bahwa preferensi masyarakat terhadap produk simpanan bank syariah cenderung memilih produk yang memberikan bagi hasil yang tinggi.

Dari aspek pembiayaan, selama setahun terakhir jumlah dana yang disalurkan meningkat 43,69 persen mencapai Rp 147,50 triliun. Penyaluran dana masih didominasi piutang murabahah sebesar Rp 88 triiliun atau tumbuh sebesar 56 persen, lalu pembiayaan musyarakah meningkat sebanyak 46 persen menjadi Rp 27,67 triliun, pembiayaan mudharabah sebesar Rp 12,02 triliun (tumbuh sekitar 17,5 persen), serta terakhir piutang qardh sebesar Rp 12,09 triliun (menurun sekitar 6,5 persen). Penyaluran pembiayaan masih didominasi oleh dana mahal, karena piutang murabahah masih menawarkan margin yang relatif tinggi dibanding suku bunga ratarata. Di akhir 2012 ini rata-rata margin bank syariah mencapai 13,69 persen.

Dana yang dikumpulkan bank syariah seluruhnya disalurkan ke sektor riil dalam bentuk pembiayaan sehingga fungsi intermediasi bank syariah di tahun 2012 menunjukkan kinerja yang positif. Nilai FDR (Financing to Deposit Ratio) mencapai 100 persen, meningkat dibanding 2011 yang hanya mencapai 88,94 persen. Semakin baiknya pembiayaan bank syariah membuat rasio NPF (Non Performing Financing) juga semakin membaik. Di akhir 2011 tercatat NPF sebesar 2,52 persen, kemudian berkurang menjadi 2,22 persen pada Desember 2012. Perbaikan kinerja pembiayaan membawa sedikit dampak negatif terhadap sisi permodalan. Capital Adequacy Ratio (CAR) bank syariah mengalami penurunan dari 16,63 persen menjadi 14,13 persen di bulan Desember 2012.

Hal positif lain juga ditunjukkan industri perbankan syariah yang telah mengurangi deposito bagi hasil tinggi seiring penurunan suku bunga simpanan. Secara gradual, hal ini memberikan pengaruh positif terhadap rentabilitas industri perbankan syariah. Kondisinya dicerminkan oleh rasio biaya operasional terhadap pendapatan operasional (BOPO) yang membaik dari 78,41 persen menjadi 74,75 persen pada Desember 2012. Return on Assets (ROA) pun ikut menguat dari 1,79 persen di 2011 menjadi 2,14 persen pada Desember 2012.

\section{Faktor Internal}

Faktor internal yang turut mendorong perkembangan bank syariah di tanah air yaitu kelengkapan regulasi. Ada dua regulasi yang mendorong secara langsung akselerasi pertumbuhan perbankan syariah di tanah air. Pertama, dikeluarkannya UU No. 21/2008 tentang Perbankan Syariah. Dalam UU tersebut diberikan beberapa insentif terkait dengan aturan-aturan untuk memudahkan pendirian Bank Umum Syariah (BUS) maupun pengonversian Unit Usaha Syariah (UUS) menjadi BUS. Apalagi dengan diikuti penerbitan UU Surat Berharga Syariah Negara/SBSN (sukuk) pada tahun yang sama. Adanya kepastian hukum ini akan memudahkan pencarian modal pendirian bank syariah baik dari sumber domestik maupun dari luar negeri 
terutama Timur Tengah, sehingga akan mempercepat proses akselerasi peningkatan porsi aset perbankan syariah secara nasional. ${ }^{4}$

Mengutip pendapat Sunarsip, ${ }^{5}$ ada delapan kontribusi UU No. 21/2008 terhadap pertumbuhan perbankan syariah di Indonesia. Pertama, adanya pasal yang mengatur percepatan pemisahan (spin off) bagi UUS yang masih menginduk pada bank konvensional. Bagi bank konvensional yang telah memiliki UUS setelah 15 tahun sejak berlakunya UU perbankan syariah atau telah memiliki aset UUS minimal 50 persen dari total nilai aset bank induknya, UUS harus dijadikan BUS.

Kontribusi kedua, UU No. 21/2008 memberi keleluasaan bagi bank syariah dalam menjalankan bisnisnya. Selain melakukan aktivitas perbankan pada umumnya, bank syariah juga diizinkan secara langsung untuk melakukan pembiayaan dengan nasabah. Bila bank konvensional akan melakukan kegiatan pembiayaan, bank tidak bisa langsung berhubungan dengan nasabah melainkan menjalin kemitraan (channeling) dengan lembaga pembiayaan terkait.

Kontribusi ketiga, adanya kewajiban mencantumkan kata syariah bagi bank syariah, kecuali bagi bank-bank syariah yang telah beroperasi sebelum berlakunya UU No 21/2008. Bagi bank konvensional yang memiliki UUS diwajibkan mencantumkan frase Unit Usaha Syariah setelah nama bank.

Kontribusi keempat, adanya sanksi bagi pemegang saham pengendali yang tidak lulus fit and proper test dari Bank Indonesia (BI). Bila pemegang saham pengendali bank syariah tidak lulus fit and proper test, yang bersangkutan harus menurunkan kepemilikan sahamnya menjadi paling banyak 10 persen. Jika tidak bersedia menurunkan kepemilikannya, maka pemegang saham tersebut akan kehilangan hak suaranya dalam RUPS. Selain itu pemegang saham juga hanya dapat memperoleh dividen maksimal 10 persen, serta nama yang bersangkutan dipublikasikan di dua media massa nasional.

Kelima, satu-satunya pemegang otoritas fatwa syariah adalah Majelis Ulama Indonesia (MUI). Karena fatwa MUI harus diterjemahkan menjadi produk hukum positif, dalam hal ini Peraturan Bank Indonesia (PBI). Dalam proses penyusunan PBI, BI membentuk komite perbankan syariah yang beranggotakan wakil dari BI, Kementerian Agama, dan unsur masyarakat dengan komposisi yang berimbang dan memiliki keahlian di bidang syariah.

Keenam, pembinaan dan pengawasan bank syariah dan UUS dilakukan oleh BI. Dalam hal mengenai masalah kepatuhan syariah (sharia compliance) yang kewenangannya berada pada MUI direpresentasikan melalui Dewan Pengawas Syariah (DPS). DPS diangkat melalui mekanisme Rapat Umum Pemegang Saham (RUPS) atas rekomendasi MUI.

Ketujuh, adanya definisi baru mengenai transaksi murabahah. Dalam definisi lama disebutkan bahwa murabahah adalah jual beli barang sebesar harga pokok barang ditambah dengan margin keuntungan yang disepakati. Menurut UU No 21/2008 disebutkan akad murabahah adalah akad pembiayaan suatu barang dengan menyebutkan harga belinya kepada pembeli dan pembeli membayarnya dengan harga yang lebih sebagai keuntungan yang disepakati. Dengan diubahnya kata jual beli dengan kata pembiayaan, 
secara implisit UU No 21/2008 ini ingin mengatakan bahwa transaksi murabahah tidak termasuk transaksi yang dikenakan pajak sebagaimana yang kini menjadi kendala bagi bank syariah.

Kontribusi kedelapan, diaturnya prinsip choice of law dalam penyelesaian sengketa yang terjadi pada perbankan syariah. Menurut UU N6 21/2008, penyelesaian sengketa yang terjadi pada perbankan syariah memang dilakukan melalui peradilan agama. Namun, sesuai prinsip choice of law, mekanisme penyelesaian di luar peradilan agama juga dibuka sepanjang isi perjanjian menyatakan demikian. Mekanisme penyelesaian di luar peradilan agama yang dapat ditempuh tersebut antara lain melalui musyawarah, mediasi perbankan, lembaga arbitrase, atau melalui pengadilan dalam lingkungan peradilan umum.

Regulasi kedua yang juga memberikan dorongan terhadap pertumbuhan perbankan syariah adalah revisi dari UU Pajak Pertambahan Nilai (PPN). Dengan adanya revisi ini, maka jasa perbankan syariah terutama yang berkaitan dengan murabahah (jual beli) dan produk turunannya tidak lagi dikenakan aturan pajak ganda. Revisi UU PPN ini menyejajarkan posisi perbankan syariah sebagai salah satu bagian dari industri jasa di bidang perbankan, sehingga terbebas dari aturan pajak pertambahan nilai. Perkembangan positif ini tentu akan meningkatkan daya saing perbankan syariah yang selama ini masih rendah yang disebabkan harga jasa yang harus dibayar konsumen atas produk bank syariah jauh lebih mahal dari harga jasa perbankan konvensional. Hal ini juga didukung kondisi di mana posisi murabahah sampai saat ini masih menjadi produk andalan bank syariah. ${ }^{6}$

\section{Faktor Eksternal}

Perkembangan ekonomi, baik global maupun nasional, berperan dalam mendorong pertumbuhan perbankan syariah. Kondisi perekonomian global di masa 2011-2012 ini masih belum menunjukkan perkembangan yang positif setelah terkena krisis keuangan yang dialami negara-negara anggota Uni Eropa. Kondisi ini ditunjukkan oleh pertumbuhan perekonomian global yang diperkirakan hanya tumbuh sebesar 3,2 persen, jauh lebih rendah dibandingkan dengan capaian pada tahun sebelumnya yang mampu mencapai angka 3,8 persen.

Muslimin Anwa dalam artikelnya ${ }^{7}$ mengungkapkan ada tiga faktor yang menjadi penyebab melambatnya pertumbuhan ekonomi dunia. Pertama, kebijakan penghematan anggaran yang diambil beberapa negara Eropa tidak berjalan dengan baik sehingga berimbas pada terjadinya pemutusan hubungan kerja (PHK) dan meningkatnya pengangguran. Meningkatnya pengangguran yang mencapai 11,6 persen pada September 2012 merupakan angka tertinggi sepanjang sejarah Eropa. Kondisi tersebut telah memicu pelemahan kinerja konsumsi yang tercermin dari keyakinan konsumen yang turun dan penjualan eceran yang hanya tumbuh moderat. Pelemahan juga terjadi di sektor industri yang banyak mengalami penurunan produksi. Pertumbuhan ekonomi kawasan Eropa untuk keseluruhan tahun 2012 diperkirakan hanya sebesar $-0,5$ persen (yoy). 
Kedua, seperti halnya negara di kawasan Eropa, pertumbuhan ekonomi AS pun masih belum signifikan sebagaimana tercermin pada sektor manufaktur yang sempat mengalami kontraksi dan moderatnya pertumbuhan indeks produksi sehingga aktivitas sektor industri sepanjang tahun 2012 terindikasi menurun. Lambannya penyerapan tenaga kerja yang tercermin dari indikator non-farm payroll yang tumbuh tidak setinggi pada 2011 telah mendorong tertekannya kinerja penjualan eceran sehingga kontribusi sisi konsumsi terhadap PDB AS mengecil.

Faktor ketiga merupakan kombinasi dari kedua faktor di atas menyebabkan pelemahan ekonomi global yang berdampak pada menurunnya permintaan terhadap barang-barang dari negara berkembang. Penurunan permintaan dunia ini melemahkan kinerja sektor eksternal negara-negara berkembang di Asia dan akhirnya pertumbuhan ekonomi negara-negara ini akan tertahan, bahkan terkoreksi melalui jalur penurunan volume perdagangan yang diikuti dengan anjloknya harga komoditas global. Harga komoditas internasional diperkirakan tumbuh negatif yang dicerminkan oleh Indeks Harga Komoditas Ekspor (IHKEx) non-migas yang tumbuh sebesar -11,9 persen per November 2012 (yoy).

Penurunan aktivitas ekonomi Eropa dan Amerika berdampak terhadap melambatnya kinerja ekonomi di kawasan Asia. Pertumbuhan ekonomi negara besar di Asia, seperti Cina pada tahun 2012 mengalami perlambatan yang cukup signifikan, diperkirakan hanya tumbuh sebesar 7,7 persen atau menurun bila dibandingkan dengan tahun sebelumnya tercatat sebesar 9,3 persen (yoy).

Perkembangan ke depan, perekonomian dunia diperkirakan mulai meningkat secara gradual dan tumbuh lebih tinggi serta harga komoditas dunia juga akan mengalami kenaikan. Sejalan dengan langkah-langkah kebijakan perbaikan ekonomi di AS dan Eropa, ekonomi dunia pada 2013 diperkirakan akan membaik, mencapai 3,6 persen. Kinerja perekonomian global yang lebih baik akan diikuti oleh peningkatan aktivitas perdagangan internasional. ${ }^{8}$

Sebagai bagian dari globalisasi, apa yang dialami ekonomi dunia dialami juga oleh perekonomian Indonesia. Pertumbuhan ekonomi keseluruhan di tahun 2012 diprediksi mencapai sekitar 6,3 persen atau menurun jika dibandingkan tahun 2011 yang tercatat 6,5 persen. Perlambatan ini dipicu oleh menurunnya kinerja eksternal sejalan dengan kinerja perdagangan dunia yang memburuk, terutama mulai semester II/2012. Namun masih kuatnya permintaan domestik, terutama konsumsi rumah tangga dan investasi, mampu menopang pertumbuhan ekonomi sehingga membuat Indonesia masuk ke dalam kelompok negara-negara yang pertumbuhannya tertinggi di dunia bersama Cina dan India. ${ }^{9}$

Seiring dengan prospek pemulihan ekonomi global, pertumbuhan ekonomi Indonesia diperkirakan kembali meningkat karena adanya peningkatan kinerja ekspor. Membaiknya pertumbuhan ekonomi Indonesia itu juga didukung oleh indikasi tetap kuatnya permintaan domestik, terutama konsumsi rumah tangga dan investasi. Meningkatnya konsumsi rumah tangga didukung oleh masih kuatnya daya beli masyarakat, dan pertumbuhan golongan usia produktif di Indonesia. 
Ada tiga prioritas utama yang harus dibenahi agar pertumbuhan ekonomi Indonesia tetap terjaga. ${ }^{10}$ Pertama, kebijakan moneter yang dirumuskan BI harus merupakan bauran kebijakan makroprudensial untuk menjaga stabilitas nilai rupiah, baik dalam bentuk inflasi yang terkendali dalam rentang sasaran 4,5+1 persen maupun volatilitas nilai tukar yang kondusif bagi perkonomian domestik.

Kedua, pemerintah perlu menjaga iklim dunia usaha dan stabilitas ekonomi nasional dengan memastikan penyerapan APBN dan mengawal implementasi berbagai isu strategis yang berjalan dengan baik dan damai. Khususnya, isu penyesuaian upah di atas UMP untuk berbagai provinsi yang berbeda-beda sesuai dengan tingkat inflasi dan Kebutuhan Hidup Layak (KHL) provinsi-provinsi tersebut. Selain itu, isu penyesuaian batas Pendapatan Tidak Kena Pajak (PTKP) menjadi (Rp 24 juta/tahun yang akan berdampak pada peningkatan daya beli masyarakat serta isu kenaikan tarif dasar listrik (TDL).

Ketiga, mendorong keseriusan para legislator dalam memprioritaskan undangundang yang harus diselesaikan secara tepat waktu. Adapun yang mendukung pertumbuhan ekonomi domestik, diantaranya hal-hal yang terkait dengan isu kenaikan BBM dan isu program redenominasi rupiah.

\section{Strategi Yang Dilakukan}

Salah satu tantangan ke depan yang dihadapi perbankan syariah yaitu harus mampu menjawab tantangan sosial ekonomi dalam pemerataan kesejahteraan ekonomi. Untuk mencapai tujuan tersebut, BI telah merancang lima strategi yang diuraikan sebagai berikut:

\section{Mengarahkan Pembiayaan Ke Sektor Produktif}

Dengan memanfaatkan luas wilayah Indonesia yang sangat besar, pembiayaan ke sektor produktif tidak hanya akan meningkatkan market share, namun juga akan mendukung perekonomian nasional menjadi lebih mandiri. Sektor produktif yang dimaksud merupakan proyek yang masuk skala prioritas dalam Masterplan Percepatan dan Perluasan Pembangunan Ekonomi Indonesia (MP3EI), misalnya konstruksi, listrik dan gas, pertanian, serta industri kreatif. Selain itu, sektor usaha mikro kecil dan menengah (UMKM) juga membutuhkan dukungan perbankan syariah untuk lebih berkembang.

Upaya memperbesar porsi pembiayaan ke sektor produktif dan berisiko rendah bisa dilakukan dengan membiayai pembangunan infrasturktur yang dibiayai APBN dengan cara melakukan sindikasi tidak saja sesama bank syariah, tetapi juga dengan bank konvensional. ${ }^{11}$

Selain sektor produktif, kontribusi lain yang bisa dilakukan perbankan syariah dalam mendukung pemerataan ekonomi adalah dengan penguatan kewirausahaan dan financial inclusion kepada kelompok masyarakat yang belum tersentuh sektor keuangan. Bila aktivitas wirausaha semakin kuat dan financial inclusion mencapai 
puncaknya, akan menunjukkan bahwa ekonomi syariah memiliki sistem perekonomian yang mampu mengangkat kesejahteraan umat.

Lembaga Penjamin Simpanan (LPS) mencatat, dari jumlah penduduk Indonesia yang berusia 15 tahun ke atas sekitar 239 juta jiwa, hanya 19,6 persen yang telah memiliki rekening di bank. Jumlah ini tertinggal dari negara-negara ASEAN maupun negara yang jumlah penduduknya melebihi Indonesia. Kondisi ini menjadi tantangan tersendiri bagi bank syariah.

Data yang dilansir LPS menunjukkan, akses masyarakat Indonesia kepada bank masih sangat kecil. Di Malaysia, sudah 66,2 persen dari 28,4 juta penduduknya yang berusia 15 tahun ke atas telah memiliki rekening. Disusul Thailand berjumlah 72,7 persen dan Singapura dengan komposisi 98,2 persen. China dan India yang jumlah penduduknya mencapai milyaran jiwa, masing-masing sudah 63,8 persen dan 35,2 persen yang memiliki rekening di bank.

Salah satu alasan masyarakat, terutama pelaku usaha kecil dan mikro, tidak menjadikan bank sebagai mitra bisnis mereka adalah biaya transaksi yang terasa tinggi. Bila bank umum masih kesulitan untuk menekan biaya transaksi, masih ada jalan lain bagi perbankan syariah dalam menguatkan akses dunia wirausaha ke bank, yaitu dengan menjalin kerja sama dengan lembaga keuangan syariah bukan bank, Baitul Mal wat Tamwil (BMT). Besarnya jumlah anggota BMT merupakan potensi untuk mendorong financial inclusion dalam menjangkau daerah terpencil.

BMT dan juga Koperasi Jasa Keuangan Syariah (KJKS) dinilai mampu menjangkau kelompok pelaku usaha kecil dan mikro yang membutuhkan akses pinjaman modal dengan biaya murah dan pengembalian ringan. Sejauh ini, BMT menunjukkan peran besar dalam menyediakan layanan keuangan syariah kepada sektor informal dan wirausaha di wilayah yang belum terjangkau perbankan syariah.

BI mencatat per Oktober 2012, jumlah dana linkage program perbankan syariah yang disalurkan ke BMT selama satu tahun mencapai Rp 439,2 miliar, jauh lebih besardari dana linkage ke BPRS yang sebesarRp 207,2 miliar dalam periode yang sama. Dengan peran tersebut, BMT bisa dijadikan oleh BUS dan UUS sebagai perpanjangan tangan mereka di daerah-daerah yang sulit terjangkau melalui serangkaian skema. Baik berupa technical assistance, penyediaan sistem pembayaran, maupun berfungsi sebagai lender of the last resort (Apex Bank). Asosiasi BMT Indonesia (Absindo) mencatat, saat ini terdapat 5.500 BMT yang tersebar di 33 provinsi Indonesia dengan lebih 22 ribu gerai dan 22 juta rekening. ${ }^{12}$

\section{Mendorong Inovasi Produk Perbankan Syariah}

Langkah ini dilakukan melalui penyempurnaan regulasi dan proses pemantapan produk. Termasuk di dalamnya adalah perbaikan kualitas pelayanan perbankan syariah agar dicapai tingkat exellence. Kualitas pelayanan perbankan syariah harus setara, bahkan melebihi pelayanan konvensional. Pengambangan produk perbankan syariah salah satunya dilakukan dengan memanfaatkan information technology (IT) 
untuk mendukung kemudahan akses pembayaran misalnya internet banking dan sms banking. ${ }^{13}$

Untuk menjawab tantangan bank syariah ke depan, dibutuhkan lebih banyak dukungan regulasi yang progresif dan berbasis pasar. Kondisi ini sangat mendesak untuk dilakukan mengingat persaingan global yang semakin ketat. Saptono mengungkapkan bahwa pertumbuhan bank syariah di Timur Tengah, Eropa dan Malaysia, tidak hanya didorong perkembangan pasar semata. Melainkan karena melimpahnya dana yang bersumber dari kenaikan harga minyak, yang kemudian dimanfaatkan oleh negara-negara Eropa dengan menerbitkan portofolio investasi syariah. Sementara perkembangan bank syariah di Malaysia karena adanya dorongan pemerintah dalam bentuk penempatan dana BUMN yang wajib ditempatkan dalam porsi tertentu di bank syariah. ${ }^{14}$

Dalam upaya pengembangan produk, bank syariah harus kreatif menciptakan inovasi produk sesuai dengan kebutuhan bisnis nasabah yang senantiasa berubah cepat. Jangan sampai peluang besar dilepaskan hanya karena kekakuan dalam berijtihad keuangan. Regulator diharapkan bersikap akomodatif dan cepat dalam merumuskan regulasi yang kondusif untuk mendukung inovasi produk. Misalnya, produk Margin During Contruction (MDC), pembiayaan multiguna, Musyarakah Mutanaqishah, treasury products, pasar uang syariah dengan komoditas syariah, sindikasi pembiayaan dengan bank konvensional, leverage model, dan sebagainya. Regulator juga seharusnya mengakomodasi akad-akad yang terjadi dalam sejarah Islam, seperti bay wafa, bay istighlal, bay istikjar, bay tawarruq fiqhiy, dan sebagainya. Asal jangan bay inah dan tawarruq munazzam. Karena, bay inah dengan tegas dilarang dalam lima hadis Nabi SAW. ${ }^{15}$

\section{Melakukan Koordinasi Dengan Otoritas Jasa Keuangan (OJK)}

Eksistensi OJK mulai dioperasikan per Januari 2013 dengan berlandaskan pada UU No. 21 Tahun 2011 Tentang Otoritas Jasa Keuangan Keuangan. Menurut UU tersebut, OJK dirancang menjadi pengawas lembaga keuangan dan non keuangan di Indonesia, termasuk di dalamnya adalah perbankan syariah.

UU tersebut mengatur struktur kerja OJK yang hanya memiliki komisioner eksekutif perbankan, komisioner eksekutif pasar modal dan komisioner eksekutif lembaga non-keuangan. Padahal di dalam masing-masing kompartemen itu terdapat unit syariahnya. Melihat kapitalisasi perbankan syariah yang saat ini sudah mencapai lima persen terhadap pangsa pasar perbankan nasional, maka sangat dibutuhkan satu deputi komisioner yang bertugas mengawasi operasional lembaga keuangan syariah, termasuk perbankan syariah.

Selama masa transisi di tahun 2013 ini, OJK harus tetap menjaga aspek kehatihatian dalam bisnis perbankan syariah. Pengawasan OJK terhadap bank syariah secara mikroprudensial misalnya meliputi kebijakan FTV (financial to value) dan minimum DP. OJK harus mendorong kinerja perbankan syariah, termasuk juga meningkatkan unit usaha syariah yang dimiliki bank konvensional. Selain itu, OJK 
harus didorong menciptakan regulasi baru yang dapat mendorong perbankan syariah melakukan pembiayaan ke sektor-sektor produktif.

Dengan hadirnya lembaga pengawas baru ini, diharapkan perbankan syariah dapat meningkatkan koordinasi dengan OJK agar tidak kehilangan momentum untuk menunjukkan peran yang lebih besar lagi di masa mendatang. Karena bagaimana pun perkembangan industri keuangan syariah telah membantu pemerintah dalam membuka lapangan kerja yang cukup luas dan berkontribusi pada berkembangnya sektor produksi yang secara tidak langsung akan meningkatkan permintaan tenaga kerja.

\section{Mendorong Sinergi Bank Syariah dan Bank Induk Agar Tercapai Efisiensi}

Sinergi bank syariah dengan bank induk harus terus ditingkatkan agar masingmaisng bank syariah dapat memenuhi aturan yang ditetapkan BI dalam hal multiple license (izin berjenjang). Dalam aturan ini BI menetapkan empat kategaori atau jenjang Bank Umum dengan Kegiatan Usaha (BUKU). BUKU I terdiri dari bank yang memiliki modal Rp 100 miliar sampai Rp 1 triliun. Bank dengan kategori BUKU II memiliki modal Rp 1 triliun sampai Rp 5 triliun, sedangkan bank dengan kategori BUKU III memiliki modal $\mathrm{Rp} 5$ triliun sampai dengan $\mathrm{Rp} 30$ triliun. Terakhir, bagi bank yang memiliki modal lebih dari Rp 30 triliun masuk ke dalam kategori BUKU IV. Namun saat ini dari 11 bank umum syariah, tidak ada bank syarah yang masuk buku III dan Buku IV. Hanya tiga bank yang masuk dalam BUKU II, selebihnya masuk kategori buku I. ${ }^{16}$ Semakin besar modal yang dimiliki bank syariah, maka gerak langkah bisnisnya semakin lincah berkembang dan ekspansi pun lebih luas, termasuk berpeluang untuk dipercaya mengelola dana haji yang selama ini masih dimonopoli oleh bank konvensional.

Sinergitas bank syariah dengan bank induk diarahkan untuk mengoptimalkan pemanfaatan fasilitas teknologi informasi, jaringan kantor, dan SDM. Baik untuk layanan pendanaan maupun pembiayaan. Tingkat efisiensi bisa dicapai dengan pembukaan outlet baru dengan menjalin kerjasama dengan lembaga-lembaga yang berjaringan masif, seperti PT. Pos, sehingga daya jangkau bisa diperluas tanpa mengeluarkan biaya yang besar. ${ }^{17}$

Dari sisi ketersediaan SDM, permasalahan yang dihadapi saat ini minimnya kuantitas SDM dan kualitas kompetensi yang masih rendah. Diperkirakan dibutuhkan sekitar 60 sampai 80 ribuan tenaga kerja yang bergerak di lembaga keuangan syariah. Jumlah ini akan semakin bertambah seiring dengan pertumbuhan industri keuangan syariah. Sedangkan saat ini baru sekitar 25 hingga 30-an universitas yang membuka kajian ekonomi Islam dan hanya mampu menghasilkan lulusan sekitar 1.000-an orang setiap tahun. ${ }^{18}$

Saat ini industri keuangan syariah masih didominasi oleh SDM konvensional yang dibekali pelatihan singkat perbankan syariah sekitar 90 persen. Sisanya sekitar 10 persen berlatar belakang syariah. Kondisi ini tentu berpengaruh terhadap kualitas "kesyariahan" industri yang ada. ${ }^{19}$ 
Jika melihat tren, pertumbuhan SDM perbankan syariah senantiasa naik dua kali lipat setiap tiga tahun. Pada tahun 2006, jumlah SDM yang bekerja di bank syariah, baik BUS, UUS maupun BPRS, mencapai angka 7.376 orang. Angka ini naik menjadi 15.443 orang pada tahun 2009 dan 30.875 orang pada bulan Oktober 2012. Ini menunjukkan dinamika pertumbuhan perbankan syariah yang luar biasa. ${ }^{20}$

Persoalan SDM merupakan hal mendasar yang perlu dipecahkan dan dalam hal ini perguruan tinggi adalah lembaga yang paling berkompeten dalam menyediakan SDM yang dibutuhkan oleh perbankan syariah. Oleh karena itu menurut Syauqi Beik, kampus harus bisa menjalankan dua fungsi utama, yaitu sebagai tempat berlangsungnya proses transfer of knowledge dan sebagai tempat pembentukan karakter (character building). Semuanya ini harus tercermin dalam desain kurikulum dan proses belajar mengajar yang dilakukan di perguruan tinggi. ${ }^{21}$

Dalam menjalankan peran yang pertama, desain kurikulum pendidikan ekonomi syariah harus menghasilkan SDM yang dapat menguasai basis teori ekonomi dan keuangan syariah, memiliki daya analisa yang tajam, dan kemampuan metodologis yang baik. Aspek filosofi dalam penguasaan teori ekonomi syariah harus juga mendapat perhatian.

Jangan sampai mahasiswa hanya memahami ekonomi syariah sebagai proses mekanistik semata, tanpa memahami filosofi utama di dalamnya. Sebagai contoh, filosofi jual beli murabahah antara lain bahwa akad tersebut harus dibangun di atas prinsip kepercayaan (trust). Pengungkapan harga pokok pembelian disertai dengan penetapan marjin profit yang diketahui oleh pembeli (nasabah) dan penjual (bank syariah) merupakan cermin dari prinsip saling percaya. Berbeda dengan jual beli biasa dimana penjual cenderung menutupi actual cost yang dikeluarkannya kepada pembeli.

Hamzah mengungkapkan, dari sisi pengembangan kurikulum ekonomi Islam, diperlukan standar kurikulum yang terintegrasi sehingga dapat menghasilkan lulusan yang berbasis ekonomi Islam, sekaligus menguasai aplikasi ilmu pengetahuan modern atau memahami Islam secara al-Turath (heritage) dan modern knowledge (economics or finance). Revisi kurikulum dilakukan untuk mengoreksi kurikulum yang selama ini hanya bertujuan untuk mendapatkan karir yang baik, hanya menyampaikan ilmu, hanya mencari keuntungan, ke arah penciptaan karakter Islam, memahami dan memformulasi insan yang kaffah, dan memahami konsep muaddab dan muaddib. ${ }^{22}$

Peran kampus yang kedua adalah tempat pembentukan karakter. Karena itu, pendidikan karakter merupakan variabel kunci dalam menghasilkan SDM yang memiliki akhlak personal dan akhlak sosial yang baik. Akhlak personal kaitannya dengan sifat atau karakter yang harus dimiliki oleh setiap individu, seperti sifat jujur, amanah, kerja keras, dan lain-lain, sementara akhlak sosial sangat erat kaitannya dengan aspek interaksi individu dengan individu lainnya, maupun dengan masyarakat secara keseluruhan. 


\section{Mendorong Sosialisasi dan Edukasi Sektor Perbankan Syariah}

Edukasi dan komunikasi juga dilakukan untuk meningkatkan pemahaman tentang kesetaraan dan keunggulan (parity and distinctiveness) produk perbankan syariah. Peningkatan pemahaman masyarakat tentang produk bank syariah harus terus digalakkan dengan gerakan-gerakan sinergis, seperti sinergi dengan Ikatan Ahli Ekonomi Islam (IAEI), MES, Forum Silaturahim Studi Ekonomi Islam (FoSSEI), kerja sama dengan ratusan perguruan tinggi se-Indonesia, ormas Islam, MUI daerah, dan sebagainya.

Dengan sosialisasi dan edukasi diharapkan dapat terbangun brand positioning yang kuat serta penerapan nilai-nilai syariah sebagai faktor pembeda dengan sistem konvensional. ${ }^{23}$

Ada beberapa upaya yang bisa dilakukan untuk meningkatkan brand positioning bank syariah di mata masyarakat. Sasaran pemasaran sebaiknya ditujukan dengan mengisi pasar yang selama ini tidak sepenuhnya terlayani oleh perbankan konvensional seperti nasabah mikro, serta sektor pertanian. Dengan mengedepankan kearifan lokal seperti mengangkat budaya-budaya bagi hasil seperti maro, mertelu, dan sebagainya. Intinya, kreativitas perlu ditingkatkan dengan memperhatikan kondisi spesifik pasar Indonesia merupakan peluang tersendiri bagi perbankan syariah untuk bisa mengangkat posisinya secara bertahap berdiri sejajar dalam sistem dual banking di Indonesia. ${ }^{24}$

Ada beberapa strategi yang bisa dilakukan oleh bank syariah untuk menegaskan posisinya di mata nasabah. Strategi ini bisa dilakukan dalam tiga tahap. ${ }^{25}$ Pertama, menyentuh sisi kognisi nasabah yaitu memberikan sosialisasi sistem dan produk perbankan syariah kepada nasabah melalui publikasi di berbagai media cetak, elektronik maupun dalam bentuk gathering, talkshow dan seminar publik. Pada tahapan ini diharapkan masyarakat mampu mengetahui dan aware tentang sistem perbankan syariah dan bagaimana sistem itu diterapkan. Diharapkan masyarakat juga memahami fungsi keberadaan perbankan syariah dari sisi personal maupun sosial.

Tahap kedua adalah menyentuh sisi emosional nasabah dengan memberikan gambaran menyeluruh tentang manfaat dan keuntungan memakai sistem perbankan syariah dari sisi bisnis (profit) maupun spirit sehingga masyarakat meyakini bahwa sistem dan produk perbankan syariah ini memang baik dan layak untuk dipakai.

Hal terpenting yang harus dilakukan dalam tahap kedua ini adalah langkah kongkrit dari pihak perbankan syariah untuk terlebih dulu memahami kebutuhan nasabah yang bisa dilakukan dengan riset pasar (marketing research). Setelah memahami kebutuhan nasabah, dilakukan strategi pembentukan citra bank syariah yang fokus, kreatif, dan konsisten. Pembentukan citra bank syariah dimulai dengan memetakan persepsi masyarakat tentang perbankan syariah. Citra bank syariah yang ada dalam benak masyarakat bisa dioptimalkan menjadi titik pembangkit citra yang diinginkan. Untuk meningkatkan citra perbankan syariah yang positif, dapat juga dilakukan dengan kegiatan sosial, mengembangkan program pengembangan masyarakat sebagai bentuk tanggung jawab perusahaan kepada publik yang biasa 
disebut corporate social responsibility (CSR). Citra bank syariah juga sangat dipengaruhi oleh sistem perbankan syariah itu sendiri, product knowledge para praktisi perbankan syariah maupun sikap dan prilaku sesuai syariah ditunjukkan para praktisi kepada nasabah.

Tahap ketiga adalah tahap aktivasi yang menyentuh sisi konasi nasabah dengan menggerakan nasabah sampai mereka benar-benar menggunakan sistem dan produk bank syariah. Keberadaan regulasi office channeling, sistem aplikasi TI yang proven untuk bank syariah, SDM yang handal, harus diimbangi dengan strategi persuasif dari semua pihak yang terkait dalam sistem perbankan syariah untuk mengajak masyarakat menggunakan sistem dan produk bank syariah, misalnya dengan mengadakan kampanye dan berbagai kegiatan massal di berbagai daerah seperti kegiatan expo serta pemberian fasilitas lain yang memudahkan masyarakat untuk menjangkau layanan bank syariah. CEO gathering juga bisa dioptimalkan untuk menjaring nasabah korporasi.

Perkembangan perbankan syariah tidak semata harus diserahkan pada keinginan pasar, namun dibutuhkan keberpihakan seperti dilibatkan dalam pengelolaan dana pemerintah pusat maupun daerah. Misalnya penyaluran dana pemberdayaan ekonomi masyarakat dengan akad syariah harus dilakukan melauli bank syariah, atau menunjuk bank syariah sebagai bank penghimpun setoran penerima negara (BPSPN), dan bahkan mengonversi bank konvensional menjadi bank syariah.

Perbankan syariah juga membutuhkan dukungan yang tegas terkait kewajiban transaksi-transaksi yang bernilai ibadah agar dilakukan secara eksklusif hanya oleh bank syariah, seperti menerima setoran haji, menerima dan mengelola dana ZISWAF (Zakat, Infak, Sedekah, dan Wakaf). Dengan demikian diperlukan sosialisasi, dorongan dan insentif untuk pengelolaan dana masjid, pesantren, lembaga pendidikan syariah, serta ormas Islam lainnya melalui perbankan syariah.

\section{Penutup}

Prospek pertumbuhan bank syariah di Indonesia masih menyimpan potensi untuk menjadi pusat keuangan syariah global. Hal ini didorong adanya kesadaran masyarakat terutama yang berpendidikan tinggi untuk menjalankan kehidupan sosial ekonomi tanpa meninggalkan nilai-nilai Islam. Kondisi tersebut harus diantisipasi dengan menyiapkan sistem pendidikan yang mengakomodasikan kebutuhan sumber daya manusia yang memiliki kemampuan mengembangkan ekonomi syariah di masa depan.

Pemberlakuan UU No 21/2008 merupakan salah satu upaya mempercepat pertumbuhan perbankan syariah dari sisi penguatan kerangka hukum. Keberadaan UU perbankan syariah diharapkan dapat membawa dampak meningkatnya portofolio investasi syariah di Indonesia, terutama yang bersumber dari investor Timur Tengah. Masih banyak strategi lain yang bisa dilakukan untuk mempercepat pertumbuhan perbankan syariah berdiri sejajar dengan bank konvensional.

Pertumbuhan bank syariah diharapkan membawa multiplier effect bagi 
perekonomian nasional. Dukungan berupa komitmen kuat dari semua pihak akan sangat menentukan perkembangan bank syariah ke depan menjadi bank yang tumbuh sehat dan kuat serta mampu memberikan kontribusi signifikan terhadap perekonomian nasional.

\section{Catatan Akhir:}

1 Bank Indonesia, "Statistik Perbankan Indonesia Desember 2012", data diakses pada tanggal 5 Februari 2013 dari www.bi.go.id.

${ }^{2}$ Ibid., hal. 2.

3 Bank Indonesia, "Statistik Perbankan Syariah Desember 2012", data diakses pada tanggal 27 Februari 2013 dari www.bi.go.id.

4 Fakultas Ekonomi Universitas Indonesia, Indonesia Economic Outlook 2010; Ekonomi Makro, Demografi, Ekonomi Syariah, (Jakarta: Grasindo, 2009), hal. 103-104.

${ }^{5}$ Sunarsip, "Beberapa Aspek Penting Dalam Perbankan Syariah”, Republika, 7 Oktober 2008.

${ }^{6}$ Fakultas Ekonomi UI, loc. cit.

7 Muslimin Anwa, “Outlook Pertumbuhan Ekonomi 2013; Tiga Langkah Prioritas", Republika, 7 Januari 2013.

${ }^{8}$ Ibid.

${ }^{9}$ Ibid.

${ }^{10}$ Ibid.

${ }^{11}$ Agustianto, "Perbankan Syariah 2013”, Republika, 26 Desember 2012.

12 "Mendorong Peran BMT", Republika, 19 Desember 2012.

${ }^{13}$ Ibid.

${ }^{14}$ Imam T. Saptono, "Strategi Perbankan Syariah: Dari Niche Menuju Mainstream”, Republika, 28 Juni 2012.

${ }^{15}$ Agustianto, loc.cit.

${ }^{16}$ Ibid.

${ }^{17}$ Ibid.

${ }^{18}$ Euis Amalia, "Potret Pendidikan Ekonomi Islam di Indonesia”, Republika, 26 Januari 2012.

19 Ibid.

${ }^{20}$ Irfan Syauqi Beik, “Tantangan SDM Ekonomi Syariah”, Republika, 27 Desember 2012.

${ }^{21}$ Ibid.

22 Muhammad Zilal Hamzah, "Tantangan dan Solusi Ekonomi Syariah 2013”, Republika, 31 Desember 2012.

${ }^{23}$ Agustianto, loc. cit.

24 Ibid.

${ }^{25}$ Ahmad Ifham Sholihin, "Strategi Bank Syariah Merebut Hati Nasabah”, Republika, 7 Juli 2006. 


\section{DAFTAR PUSTAKA}

Agustianto, "Perbankan Syariah 2013”, Republika, (26 Desember 2012).

Amalia, Euis, "Potret Pendidikan Ekonomi Islam di Indonesia", Republika, (26 Januari 2012).

Anwa, Muslimin, "Outlook Pertumbuhan Ekonomi 2013; Tiga Langkah Prioritas", Republika, (7 Januari 2013).

Bank Indonesia, “Statistik Perbankan Indonesia Desember 2012”, www.bi.go.id. , "Statistik Perbankan Syariah Desember 2012", www.bi.go.id.

Beik, Irfan Syauqi, “Tantangan SDM Ekonomi Syariah”, Republika, (27 Desember 2012).

Fakultas Ekonomi Universitas Indonesia, Indonesia Economic Outlook 2010; Ekonomi Makro, Demografi, Ekonomi Syariah, Jakarta: Grasindo, 2009.

Hamzah, Muhammad Zilal, "Tantangan dan Solusi Ekonomi Syariah 2013", Republika, (31 Desember 2012).

Saptono, Imam T, "Strategi Perbankan Syariah: Dari Niche Menuju Mainstream", Republika, (28 Juni 2012).

Sholihin, Ahmad Ifham, "Strategi Bank Syariah Merebut Hati Nasabah", Republika, (7 Juli 2006).

Sunarsip, "Beberapa Aspek Penting Dalam Perbankan Syariah", Republika, (7 Oktober 2008).

"Mendorong Peran BMT”, Republika, (19 Desember 2012).

Zaini Ibrahim, dosen pada Fakultas Syari'ah dan Ekonomi Islam IAIN Sultan Maulana Hasanuddin Banten. 